\title{
Fate of anthropogenic micropollutants during wastewater treatment and influence on receiving surface water
}

\author{
A. Bruchet \& M. L. Janex-Habibi \\ CIRSEE, Suez-Environment Le Pecq, France
}

\begin{abstract}
More than 110 volatile and base-neutral compounds or groups of compounds with concentrations exceeding $0.1 \mu \mathrm{g} / \mathrm{L}$ were identified in a wastewater treatment plant, at different stages of treatment. Individual concentrations ranged from $0.1 \mu \mathrm{g} / \mathrm{L}$ to $1 \mathrm{mg} / \mathrm{L}$. The concentrations of many micropollutants were increased after mixing the raw water with recycled waters from the sludge drying process. Six compounds listed among the 33 priority pollutants from the Water Framework Directive, were detected. Due to the high efficiency of the treatment process and to the high dilution ratio at the outlet, this plant showed little influence on the receiving water.

Keywords: base-neutral fraction, glycol ethers, hydrocarbons, nonylphenols, phtalates, priority pollutants, volatile organics, wastewater treatment.
\end{abstract}

\section{Introduction}

Various natural and synthetic compounds have been shown to interfere with animal and human endocrine systems among them organochlorine pesticides, plasticizers, detergents, natural and synthetic hormones, organometallics or heavy metals. A relationship is suspected between these compounds and hormonal dependant cancers, in particular breast and testicular cancers. Simultaneously, more and more researchers are also discovering drugs and their metabolites as well as personal care products in drinking water resources. Although the levels of drugs found can be considered as rather small compared to the amounts prescribed to patients, there is concern about their long-term effects on humans as well as on aquatic organisms. One of the questions raised is 
whether drugs such as antibiotics could induce the proliferation of resistant microbes that would in turn damage human health.

Urban wastewaters are one of the primary sources of synthetic organics discharged into environmental waters due to their wide use as household products (detergents, cosmetics and paints), or natural excretion by humans (drugs and metabolites, and synthetic hormones). Most studies usually target a specific group of micropollutants, however wastewaters contain hundreds of micropollutants and, as the number of chemicals being tested for their reproductive or other toxicological effects is growing, many compounds that are not taken into account today might be considered as undesirable in the future. The objective of this study was hence to implement an analytical scheme capable of identifying as many micropollutants as possible in a single waste or natural water sample to create a database for future reference. This paper reports the application of part of this scheme to the analysis of natural and man-made contaminants in a urban wastewater plant sampled at different treatment stages and discusses the fate of relevant compounds in detail. The influence of the plant effluent on the receiving water is also discussed.

\section{Analytical methods}

The analytical methods implemented were part of a broad screening analytical scheme that was described elsewhere [1] Briefly, this scheme allows the recovery of volatile compounds by purge-and-trap-GC/MS, of a base-neutral and acidic fraction after sequential liquid-liquid extraction with methylene chloride at $\mathrm{pH} 11$ then $\mathrm{pH}$ 2. The base-neutral fraction is injected directly in GC/MS then derivatized by silylation to quantitate sterols, while the acidic fraction is injected without derivatization on a polar column and after methylation on a non-polar column to study aliphatic and aromatic carboxylic acids as well as phenols. Solid-phase extraction on a polymeric PLRPS resin followed by diazomethane methylation and GC/MS is used to specifically quantitate Linear alkylbenzene sulfonates (LAS) while chelating agents such as NTA and EDTA are recovered by ion exchange, then derivatized by butylation prior to GC/MS analysis.

\section{Description of the wastewater plant}

The wastewater plant investigated which was built in 1990 and is located southeast of the Paris area treats the effluents from 250, 000 inhabitants $(48,500$ $\mathrm{m}^{3} /$ day). This plant comprises the following treatment steps: screening, mixing of the raw waters with recycled waters from digested sludge dehydration treatment (with belt filters), grease and sand removal, primary settling, low food to mass ratio activated sludge treatment and final clarification, (fig. 1). At the time of sampling the plant raw water showed $\mathrm{DOC}, \mathrm{COD}$ and $\mathrm{BDO}_{5}$ values equal to $61 \mathrm{mg} / \mathrm{L}, 215 \mathrm{mg} \mathrm{O}_{2} / \mathrm{L}, 80 \mathrm{mg} / \mathrm{L} \mathrm{O}_{2} / \mathrm{L}$ in the influent, and $16 \mathrm{mg} / \mathrm{L}, 30 \mathrm{mg}$ $\mathrm{O}_{2} / \mathrm{L},<5 \mathrm{mg} \mathrm{O}_{2} / \mathrm{L}$ in the effluent. The plant was hence removing $75 \%$ of the organic matter (estimated by DOC) and at least $95 \%$ of biodegradable organic matter $\left(\right.$ as $\left.\mathrm{BOD}_{5}\right)$. The treated wastewaters are discharged into the Seine River, 
therefore two samples from this river were collected upstream and downstream to assess any influence of the plant on the river water quality. The plant itself was sampled at five different stages, including the raw water intake, the raw water after mixing with recycled waters from sludge treatment, after sand and grease removal, after primary settling and the treated water after the secondary clarifiers. 24 hour composite samples were collected in glass containers.

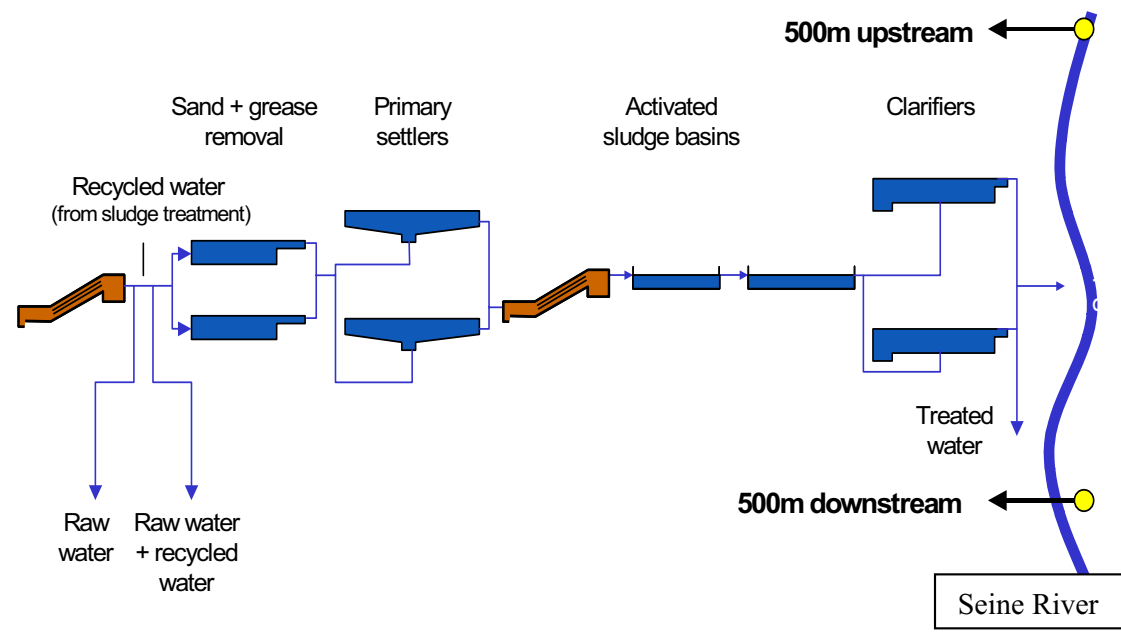

Figure 1: Schematic of the wastewater plant investigated.

\section{Results}

Because of the rather high dilution in the receiving surface water (Seine river), at least 100 fold during average summer flow conditions, it was not deemed relevant to report compounds present at levels less than $0.1 \mu \mathrm{g} / \mathrm{L}$. Also, because carrying out a true quantitative work for all compounds detected was considered as impossible, except for specific groups of interest, the concentration of volatile and semi-volatile compounds was estimated relative to internal standards as described by Nguyen et al [1]. As the results for select compounds at the present plant were already reported elsewhere [2], the present paper reports in detail for the first time the exhaustive results obtained for volatile compounds and baseneutral compounds.

\subsection{Volatile organic compounds}

Volatile organic compounds identified in the raw wastewater, in the raw wastewater mixed with recycled waters, in the water after primary settling, and in the treated water after secondary settling, are listed in table 1. More than 50 volatile compounds were detected at levels exceeding $0.1 \mu \mathrm{g} / \mathrm{L}$. They 
Table 1: $\quad$ Volatile compounds at different stages of treatment $\left(\mu \mathrm{g} / \mathrm{L}^{*}\right)$.

\begin{tabular}{|c|c|c|c|c|}
\hline compounds & raw water & $\begin{array}{c}\text { raw+recycled } \\
\text { water }\end{array}$ & $\begin{array}{c}\text { after primary } \\
\text { settling }\end{array}$ & $\begin{array}{l}\text { treated } \\
\text { water }\end{array}$ \\
\hline \multicolumn{5}{|l|}{ Hydrocarbons } \\
\hline benzene & 1.5 & 10.7 & $<0.1$ & 0.5 \\
\hline toluene & 3.4 & 33.3 & 3.8 & 0.3 \\
\hline ethylbenzène & 0.5 & 0.7 & 0.6 & 0.1 \\
\hline xylenes & 6.7 & 13.7 & 13.5 & 0.3 \\
\hline alkylbenzenes $\Phi C_{3}$ & 17.7 & 33.9 & 111.9 & 0.1 \\
\hline méthylstyrene & $<0.1$ & $<0.1$ & $<0.1$ & 0.3 \\
\hline alkylbenzenes $\Phi C_{4}$ & 9.6 & 19.5 & 2.5 & $<0.1$ \\
\hline cymene & $<0.1$ & 4.3 & $<0.1$ & $<0.1$ \\
\hline p-ethinyltoluene & $<0.1$ & 11.8 & $<0.1$ & $<0.1$ \\
\hline dimethylstyrenes & 0.4 & 0.3 & $<0.1$ & $<0.1$ \\
\hline $\begin{array}{l}\text { 2-methyldecahydro- } \\
\text { naphtalene }\end{array}$ & $<0.1$ & 0.5 & 0.7 & $<0.1$ \\
\hline ethylcyclobutane & 0.4 & $<0.1$ & $<0.1$ & $<0.1$ \\
\hline alkenes $\mathrm{C}_{9}$ & $<0.1$ & 5.2 & 6.7 & $<0.1$ \\
\hline alkane $\mathrm{C}_{8}$ & $<0.1$ & 3.3 & $<0.1$ & $<0.1$ \\
\hline alkanes $\mathrm{C}_{9}$ & 1.0 & 3.1 & 3.0 & $<0.1$ \\
\hline alkanes $\mathrm{C}_{10}$ & 33.7 & 100.9 & 207.1 & $<0.1$ \\
\hline alkanes $\mathrm{C}_{11}$ & 58.1 & 115.0 & 123.8 & 0.6 \\
\hline \multicolumn{5}{|l|}{ Halogenated compounds } \\
\hline 1.1-dichloroethane & 9.3 & 36.0 & 13.9 & $<0.1$ \\
\hline 1.1.1- trichloroethane & 1029.0 & 735.0 & 559.0 & 17.2 \\
\hline 1.2- dichloroethylene & 1.3 & 13.7 & 0.9 & $<0.1$ \\
\hline trichloroethylene & 6.8 & 11.0 & 4.5 & 0.5 \\
\hline chloroform & 4.7 & 16.8 & 3.3 & $<0.1$ \\
\hline tetrachloroethylene & 5.8 & 6.6 & 2.9 & $<0.1$ \\
\hline bromochlorométhane & 0.3 & 2.9 & $<0.1$ & $<0.1$ \\
\hline dibromomethane & $<0.1$ & 2.4 & $<0.1$ & $<0.1$ \\
\hline dichlorobenzene & $<0.1$ & 16.5 & $<0.1$ & $<0.1$ \\
\hline \multicolumn{5}{|l|}{ Oxygenated compounds } \\
\hline 1.2-epoxybutane & 13.7 & 27.9 & 20.5 & $<0.1$ \\
\hline butanone & $<0.1$ & 23.6 & 0.2 & $<0.1$ \\
\hline butyl formate & $<0.1$ & 3.4 & 0.4 & $<0.1$ \\
\hline methylisobutylketone & $<0.1$ & $<0.1$ & 0.5 & $<0.1$ \\
\hline 2-ethyl-4-methyl-1.3-dioxolane & $<0.1$ & $<0.1$ & 0.4 & $<0.1$ \\
\hline dimethyl-1.4-dioxolane & $<0.1$ & $<0.1$ & 1.4 & $<0.1$ \\
\hline
\end{tabular}


Table 1: $\quad$ (continued).

\begin{tabular}{|c|c|c|c|c|}
\hline compounds & raw water & $\begin{array}{c}\text { raw+recycled } \\
\text { water }\end{array}$ & $\begin{array}{c}\text { after primary } \\
\text { settling }\end{array}$ & $\begin{array}{c}\text { treated } \\
\text { water }\end{array}$ \\
\hline Oxygenated compounds & & & & \\
\hline dimethyl-1.4-dioxolane & $<0.1$ & $<0.1$ & 1.4 & $<0.1$ \\
\hline ketone & 0.3 & $<0.1$ & $<0.1$ & 0.1 \\
\hline Alcohols & 15.6 & 23.8 & 36.7 & 1.0 \\
\hline alkenol & 2.3 & $<0.1$ & $<0.1$ & $<0.1$ \\
\hline $\begin{array}{c}\text { Nitrogenous and sulfur } \\
\text { compounds }\end{array}$ & & & & \\
\hline 1-methylthio-1-propene & $<0.1$ & $<0.1$ & 0.2 & $<0.1$ \\
\hline dimethyldisulfide & 18.6 & 6.5 & 0.6 & $<0.1$ \\
\hline dimethyltrisulfide & 2.2 & $<0.1$ & $<0.1$ & $<0.1$ \\
\hline 1-butyl-1.2.4-triazole & $<0.1$ & 1.1 & 0.9 & $<0.1$ \\
\hline Terpenes & & & & \\
\hline pinene & 2.7 & 5.3 & 4.7 & $<0.1$ \\
\hline limonene & 17.2 & 37.6 & 22.7 & $<0.1$ \\
\hline camphene & $<0.1$ & $<0.1$ & 3.9 & $<0.1$ \\
\hline menthenol & 0.2 & $<0.1$ & 0.5 & $<0.1$ \\
\hline
\end{tabular}

- concentrations estimated relative to 2-Bromo-1-chloropropane internal standard.

primarily comprise aliphatic (with a maximum for $\mathrm{C}_{10}-\mathrm{C}_{11}$ alkanes) and aromatic hydrocarbons (with a maximum for $\mathrm{C}_{4}$-alkylbenzenes), chlorinated solvents (with an unusually high level of 1,1,1-trichloroethylene), odorous sulfides, terpenes commonly used in household products, and oxygenated compounds. The unusually high concentration of 1,1,1-trichloroethane reveals an industrial contamination of the raw water as this solvent is commonly used in many industries as a degreasing agent for metal surfaces. The $\mathrm{C}_{1}$ to $\mathrm{C}_{4}$-alkylbenzenes indicate a contamination with a light hydrocarbon oil (gasoline) while the heavier alkanes with a maximum in $\mathrm{C}_{10}-\mathrm{C}_{11}$ indicate contamination with an intermediate oil such as fuel oil or diesel oil. Epoxides such as 1,2-epoxybutane are important intermediates for industrial chemical syntheses. Although present at low concentrations, 2-ethyl-4-methyl-1.3-dioxolane is worth mentioning as this chemical which arises as an impurity during the manufacture of polyester resins, has already induced several taste and odor episodes in drinking waters produced from natural waters contaminated by this compound. Several of the volatile compounds identified are listed among the 33 priority pollutants from the European Framework water directive [3] for which environmental quality standards (EQS) are currently being proposed in Europe [4] or provisional EQS already exist in specific EU countries such as France [5]. These include benzene, trichloroethylene and tetrachloroethylene. At the time of sampling, the plant investigated exhibited an excellent removal efficiency for all volatile compounds 
and only 1,1,1-trichloroethane was released at a level exceeding $1 \mu \mathrm{g} / \mathrm{L}$. From a plant management point of view, table 1 clearly indicates that recycling the waters from the sludge dehydration process can drastically increase the concentration of compounds in the water before treatment (see $\mathrm{C}_{10}-\mathrm{C}_{11}$ alkanes, chloroform, 1,2-epoxybutane, etc) or recycle compounds that are not present in the raw water at the time of sampling (see butanone, butylformate, dichlorobenzene).

\subsection{Base-neutral compounds}

A wide range of base-neutral compounds were detected after liquid-liquid extraction at basic $\mathrm{pH}$, table 2 . Some of the compounds listed in table 1 were also detected in the base-neutral fraction. In this case, the compounds were listed in the fraction where their concentration was the highest, which means when they were measured with the most adapted analytical technique. The base-neutral fraction was dominated by a series of alkanes ranging from $C_{8}$ to $C_{29}$, with maxima for $\mathrm{C}_{10}, \mathrm{C}_{11}, \mathrm{C}_{12}$ (characteristic of diesel oil or fuel oil), and secondary maxima for $\mathrm{C}_{17}, \mathrm{C}_{23}, \mathrm{C}_{24}, \mathrm{C}_{25}$ and $\mathrm{C}_{26}$. The hypothesis of a contamination by diesel oil tends to be confirmed by the presence of low levels of paH's and alkyl paH's in this fraction. Some of them, which remain at levels below $0.1 \mu \mathrm{g} / \mathrm{L}$ were listed in table 2 because they were found at higher levels at other stages of treatment during this campaign (one sample was also collected after sand and grease removal and two samples were collected in the Seine river). Fluoranthene and naphthalene are on the list of priority substances from the Water Framework directive, with proposed EQS values of 0.1 and $2.4 \mu \mathrm{g} / \mathrm{L}$ for inland waters. Cycloalkanes are present in minor amounts in oil products. Alkenes from $\mathrm{C}_{10}$ to $\mathrm{C}_{18}$ may arise as impurities during the manufacture of polyolefin plastics or from the cracking of alkanes in used oil products.

The $\mathrm{C}_{10}$ to $\mathrm{C}_{13}$-alkylbenzenes arise as impurities during the manufacture of linear alkylbenzene sulfonate detergents. As a matter of fact LAS were found at levels close to $7 \mathrm{mg} / \mathrm{L}$ in the raw wastewater and after mixing with the recycled waters. Therefore these higher molecular weight alkylbenzenes are good indicators of the presence of LAS. In addition to the halogenated compounds detected in the volatile fraction, traces of 2 chlorinated solvents, 1,1,2-trichloroethane and trichloropropene were found in the base-neutral fraction. Glycol ethers such as 2-butoxyethanol or 2-butoxyethoxyethanol are outstanding oxygenated compounds in the base-neutral fraction. The toxicological properties, origins and fate of these water-based solvents were discussed in a previous paper [2]. 2-butoxyethoxy ethanol drastically increases (to $1.27 \mathrm{mg} / \mathrm{L}$ ) after mixing with the recycled waters from sludge drying. This compound, which shows the highest concentration in the base-neutral fraction, is totally eliminated by the water treatment process. Several weakly estrogenic phtalates (diethyl, and butylbenzylphtalate) were also efficiently eliminated. It is noteworthy that butylisobutylphtalate was less efficiently removed than its linear isomer, butylbenzylphtalate. Like diisooctylphtalate, this compound exceeds $10 \mu \mathrm{g} / \mathrm{L}$ in the treated water. Nonylphenols, also listed among the 33 EU priority pollutants, are considered as the main contaminants responsible for the 
Table 2: $\quad$ Base-neutral compounds at different stages of treatment $(\mu \mathrm{g} / \mathrm{L})$.

\begin{tabular}{|c|c|c|c|c|}
\hline Compounds & Raw water & \begin{tabular}{|c|} 
Raw+recycled \\
water \\
\end{tabular} & \begin{tabular}{|c|} 
After primary \\
settling
\end{tabular} & $\begin{array}{c}\text { Treated } \\
\text { water }\end{array}$ \\
\hline \multicolumn{5}{|l|}{ Hydrocarbons } \\
\hline Naphtalene & $<0,1$ & 0,2 & $<0,1$ & 0,1 \\
\hline Methylnaphtalene & $<0.1$ & $<0.1$ & $<0.1$ & $<0.1$ \\
\hline Alkylbenzenes $\Phi \mathrm{C}_{10}$ & 1.2 & 6.6 & 3.8 & $<0.1$ \\
\hline Alkylbenzenes $\Phi C_{11}$ & 5.5 & 17.1 & 20.5 & $<0.1$ \\
\hline Alkylbenzenes $\Phi C_{12}$ & 6.2 & 24.9 & 24.2 & $<0.1$ \\
\hline Alkylbenzenes $\Phi C_{13}$ & 4.5 & 9.3 & 2.3 & $<0.1$ \\
\hline Fluoranthene & $<0.1$ & $<0.1$ & $<0.1$ & $<0.1$ \\
\hline Pyrene & 0.5 & $<0.1$ & $<0.1$ & $<0.1$ \\
\hline Methylphenanthrene & $<0.1$ & $<0.1$ & $<0.1$ & 0.1 \\
\hline Benzophenanthrene & $<0.1$ & $<0.1$ & $<0.1$ & $<0.1$ \\
\hline 1-Ethyl-4-methylcyclohexane & $<0.1$ & 0.3 & 0.2 & $<0.1$ \\
\hline 1-Methyl-3-isobutylcyclopentane & $<0.1$ & 1.7 & 0.3 & $<0.1$ \\
\hline 1.4-Dimethyl-2-isobutylcyclohexane & $<0.1$ & 0.1 & $<0.1$ & $<0.1$ \\
\hline Pentylcyclohexane & 0.4 & 0.2 & 0.3 & $<0.1$ \\
\hline Alkylcyclohexane & 1.9 & 1.9 & $<0.1$ & $<0.1$ \\
\hline Alkenes from $\mathrm{C}_{10}$ to $\mathrm{C}_{18}$ & 4.8 & 15.6 & 11.9 & 0.3 \\
\hline Alkanes $\mathrm{C}_{8-} \mathrm{C}_{29}$ & 213.8 & 483.5 & 338.2 & 2.0 \\
\hline Squalene & 66.9 & 129.2 & 69.0 & $<0.1$ \\
\hline \multicolumn{5}{|l|}{ Halogenated compounds } \\
\hline 1.1.2-Trichloroethane & $<0.1$ & $<0.1$ & 0.2 & $<0.1$ \\
\hline 1.1.2-Trichloropropene & $<0.1$ & $<0.1$ & $<0.1$ & $<0.1$ \\
\hline \multicolumn{5}{|l|}{ Oxygenated compounds } \\
\hline 2-Ethoxybutane & 0.8 & 7.1 & 0.4 & 0.2 \\
\hline $\begin{array}{l}\text { 2-Methanol-2.4-dimethyl-1.3- } \\
\text { dioxolane }\end{array}$ & 1.7 & 4.9 & 2.3 & $<0.1$ \\
\hline Cyclohexanone & $<0.1$ & 23.8 & $<0.1$ & $<0.1$ \\
\hline 2-Butoxyethanol & 110.2 & 140.6 & 94.0 & $<0.1$ \\
\hline [2-Ethoxy-1-methoxyethoxy] ethene & $<0.1$ & 0.9 & $<0.1$ & $<0.1$ \\
\hline 2-Methoxyethyl ether & 1.5 & $<0.1$ & 2.0 & 0.5 \\
\hline Dipropylene glycol methyl ether & 10.1 & 24.8 & 25.4 & 0.6 \\
\hline Alcohol & 51.0 & 41.3 & 19.8 & 1.3 \\
\hline 3.7-Dimethyl-1.7-octadiol & 21.0 & 11.3 & 12.8 & $<0.1$ \\
\hline Decanol & 0.3 & 9.3 & $<0.1$ & $<0.1$ \\
\hline 2-Butoxyethoxyethanol & 317.0 & 1270.0 & 306.0 & $<0.1$ \\
\hline 4-Tertbutylcyclohexanone & 0.9 & 1.4 & $<0.1$ & 0.1 \\
\hline
\end{tabular}


Table 2: $\quad$ (continued).

\begin{tabular}{|c|c|c|c|c|}
\hline Compounds & Raw water & $\begin{array}{c}\text { Raw+recycled } \\
\text { water }\end{array}$ & $\begin{array}{c}\text { After primary } \\
\text { settling }\end{array}$ & $\begin{array}{c}\text { Treated } \\
\text { water }\end{array}$ \\
\hline \multicolumn{5}{|l|}{ Oxygenated compounds } \\
\hline Phenyl pentanoate & $<0.1$ & 3.7 & $<0.1$ & $<0.1$ \\
\hline $\begin{array}{l}\text { 1.1-Methyl-2-(2-propenyloxy)ethoxy- } \\
\text { 2-propanol }\end{array}$ & 3.9 & $<0.1$ & $<0.1$ & $<0.1$ \\
\hline Dimethanonaphtalenol & 5.2 & $<0.1$ & $<0.1$ & $<0.1$ \\
\hline 2.4-Diterbutylphenol & 0.8 & 0.6 & 0.5 & 0.1 \\
\hline 4-Methyl-2.6-ditertbutylphenol (BHT) & 1.0 & 0.5 & 0.9 & 0.3 \\
\hline Tributyl phosphate & $<0.1$ & 0.2 & $<0.1$ & 0.4 \\
\hline Diethyl phtalate & 12.5 & 26.9 & 20.6 & $<0.1$ \\
\hline Nonylphenols & $<0.1$ & 5.9 & $<0.1$ & $<0.1$ \\
\hline $\begin{array}{l}\text { Hexyl 2-hydroxybenzoate (hexyl } \\
\text { salicylate) }\end{array}$ & $<0.1$ & 0.8 & $<0.1$ & $<0.1$ \\
\hline Butyl isobutyl phtalate & 0.8 & 82.1 & $<0.1$ & 11.1 \\
\hline Isopropyl hexadecanoate & 1.8 & 2.0 & $<0.1$ & $<0.1$ \\
\hline 2-Hydroxy-4-methoxybenzophenone & 1.6 & 0.9 & $<0.1$ & $<0.1$ \\
\hline Hexadecanal & 1.9 & 5.0 & $<0.1$ & $<0.1$ \\
\hline Benzylbutyl phtalate & $<0.1$ & 21.3 & $<0.1$ & $<0.1$ \\
\hline Butoxyethanol phosphate & 15.7 & 7.8 & $<0.1$ & 0.7 \\
\hline Diisooctyl phtalate & 46.4 & 102.2 & 42.9 & 16.3 \\
\hline \multicolumn{5}{|l|}{ Nitrogenous and sulfur compounds } \\
\hline Benzothiazole & $<0.1$ & $<0.1$ & $<0.1$ & $<0.1$ \\
\hline Dibutylthiophene & $<0.1$ & $<0.1$ & $<0.1$ & 0.3 \\
\hline 2-(Methylthio)benzothiazole & $<0.1$ & 0.3 & $<0.1$ & 0.4 \\
\hline Methylisothiazole & $<0.1$ & $<0.1$ & $<0.1$ & $<0.1$ \\
\hline Pyridine & $<0.1$ & 0.7 & 0.9 & $<0.1$ \\
\hline N.N-Dimethylformamide & $<0.1$ & 0.3 & 0.1 & $<0.1$ \\
\hline 3-Isothiocyanato-1-propene & 0.4 & 0.5 & 0.2 & $<0.1$ \\
\hline Indole & $<0.1$ & 16.8 & $<0.1$ & $<0.1$ \\
\hline Methylindole & 2.5 & 4.6 & $<0.1$ & $<0.1$ \\
\hline $\begin{array}{l}\text { 3-(1-Methyl-2-pyrrolidinyl)pyridine } \\
\text { (Nicotine) }\end{array}$ & $<0.1$ & $<0.1$ & $<0.1$ & $<0.1$ \\
\hline 2-Indolinone & $<0.1$ & $<0.1$ & 0.1 & $<0.1$ \\
\hline N.N-Diethyl-3-methylbenzamide & $<0.1$ & $<0.1$ & $<0.1$ & 0.4 \\
\hline Cafeine & 34.1 & 70.1 & 52.0 & 0.3 \\
\hline 1-Methyl-2-pyrrolidinone & 10.5 & 8.4 & 8.9 & $<0.1$ \\
\hline \multicolumn{5}{|l|}{ Terpenes } \\
\hline Menthane & 0.5 & $<0.1$ & 0.8 & $<0.1$ \\
\hline Linalol & 12.5 & 8.4 & 9.7 & $<0.1$ \\
\hline
\end{tabular}


Table 2: $\quad$ (continued).

\begin{tabular}{|c|c|c|c|c|}
\hline Compounds & Raw water & $\begin{array}{c}\text { Raw+recycled } \\
\text { water }\end{array}$ & $\begin{array}{c}\text { After primary } \\
\text { settling }\end{array}$ & $\begin{array}{c}\text { Treated } \\
\text { water }\end{array}$ \\
\hline Terpenes & & & & \\
\hline Carveol & 0.7 & $<0.1$ & $<0.1$ & $<0.1$ \\
\hline Unknown terpenes $\mathrm{C}_{10} \mathrm{H}_{16}$ & 10.2 & 14.0 & 7.4 & $<0.1$ \\
\hline Terpineol & 2.6 & 1.6 & 2.6 & $<0.1$ \\
\hline Camphor & 3.5 & 4.7 & 14.9 & $<0.1$ \\
\hline Menthenol & 10.1 & 10.9 & $<0.1$ & $<0.1$ \\
\hline Plinol & $<0.1$ & 0.7 & 0.3 & $<0.1$ \\
\hline Bornyl acetate & 1.2 & 1.0 & $<0.1$ & $<0.1$ \\
\hline Sterols & & & & \\
\hline Cholesteryl pelargonate & 5.4 & 8.2 & $<0.1$ & $<0.1$ \\
\hline Coprostanone & 28.0 & 66.5 & 23.8 & 0.8 \\
\hline Coprostanol & 37.0 & 207.7 & 381.7 & $<0.1$ \\
\hline
\end{tabular}

estrogenicity of wastewater effluents, together with the natural estrogenic hormones from humans. As shown in table 2, these compounds, undetected in the raw water, are brought along with the recycled waters, because they tend to be formed during anaerobic stages of sludge treatment. This is due to the anaerobic degradation of heavier alkylphenolpolyethoxylates which are always present at much higher levels than nonylphenols in raw waters. These precursors were not measured as they require an additional analytical method. Because of their use as plastic additives tert-butylphenol and its alkyl derivatives such as BHT, as well as organic phosphate additives, are commonly found in wastewaters. Tert-butylphenol and tributylphosphate are considered as ecotoxicologically relevant by the French institute (INERIS) in charge of implementing the Water Framework directive in France.

A number of drugs (caffeine, nicotine) and personal care products (2-hydroxy-4-methoxybenzophenone or Sunscreen UV 15) as well as terpenic compounds used as fragrances in household products were also detected. 3-Isothiocyanato-1-propene has been found carcinogenic to male rats [5], while $\mathrm{N}, \mathrm{N}$-dimethylformamide is toxic for reproduction. Pyridine, a synthetic intermediate in laboratory and industry is a highly toxic compound which may cause central nervous system depression, gastrointestinal upset and liver and kidney damage.

Among the ca.75 compounds or groups of compounds found in the baseneutral fraction, only the following exceeded $1 \mu \mathrm{g} / \mathrm{L}$ in the treated water: $\mathrm{C}_{8}-\mathrm{C}_{29}$ alkanes $(2 \mu \mathrm{g} / \mathrm{L})$, one alcohol $(1.3 \mu \mathrm{g} / \mathrm{L})$, butylisobutylphtalate $(11.1 \mu \mathrm{g} / \mathrm{L})$ and diisooctylphtalate $(16.3 \mu \mathrm{g} / \mathrm{L})$, confirming the excellent efficiency of the plant. 


\section{Conclusions}

More than 110 volatile and base-neutral compounds or groups of compounds (many compounds comprise multiple isomers or homologues) with concentrations exceeding $0.1 \mu \mathrm{g} / \mathrm{L}$ were identified in a wastewater treatment plant, at different stages of treatment. Individual concentrations ranged from $0.1 \mu \mathrm{g} / \mathrm{L}$ to $1 \mathrm{mg} / \mathrm{L}$. The concentrations of many micropollutants were increased after mixing the raw water with recycled waters from the sludge drying process but the secondary treatment (activated sludge followed by settling) was quite efficient at removing them. Six compounds listed among the 33 priority pollutants from the Water Framework directive were detected, including benzene, trichloroethylene, tetrachloroethylene, fluoranthene, naphthalene and nonylphenols. These compounds were detected at a maximum concentration of $0.5 \mu \mathrm{g} / \mathrm{L}$ at the plant outlet.

Many of the other compounds identified are quite undesirable in natural waters whether for the ecological status or for the production of drinking water due to their toxicological or ecotoxicological properties or because of their potential to induce taste and odour problems in finished drinking waters.

Due to the high efficiency of the treatment process, only the following compounds exceeded $1 \mu \mathrm{g} / \mathrm{L}$ in the treated water: $\mathrm{C}_{8}-\mathrm{C}_{29}$ alkanes $(2 \mu \mathrm{g} / \mathrm{L})$, one alcohol $(1.3 \mu \mathrm{g} / \mathrm{L})$, butylisobutylphtalate $(11.1 \mu \mathrm{g} / \mathrm{L})$ and diisooctylphtalate $(16.3 \mu \mathrm{g} / \mathrm{L})$ and $1,1,1$-trichloroethane $(17.2 \mu \mathrm{g} / \mathrm{L})$. Because the dilution ratio into the receiving river exceeds a 100 fold factor, even during low summer flow conditions, this would entail a maximum input of about $20 \mathrm{ng} / \mathrm{L}$ in the worst case, after full mixing, and of less than $1 \mathrm{ng} / \mathrm{L}$ for most individual compounds identified. As a matter of fact, the present analytical campaign showed that only 1,1,1-trichloroethane and LAS (not shown here) increased in the river $500 \mathrm{~m}$ downstream of the plant, from 0.2 to $0.8 \mu \mathrm{g} / \mathrm{L}$ for trichloroethane and from 35 to $56 \mu \mathrm{g} / \mathrm{L}$ for LAS.

The high dilution ratio of this wastewater effluent into the Seine River also implies that the six priority pollutants identified, which are found at a maximum concentration of $0.5 \mu \mathrm{g} / \mathrm{L}$ in the treated water, will not exceed their Environmental Quality Standard in the river.

\section{References}

[1] Nguyen, D.K., Bruchet, A. \& Arpino, P., High Resolution Capillary GC-MS Analysis of Low Molecular Weight Organic Compounds in Municipal Wastewater. Journal of High Resolution Chromatography, 17(3), pp. 153-159, 1994.

[2] Bruchet, A., Prompsy, C., Filippi, G. \& Souali, A., A broad spectrum analytical scheme for the screening of endocrine disruptors (Eds), pharmaceuticals and personal care products in wastewaters and natural waters. Water Science and Technology, 46(3), pp. 97-104, 2002.

[3] Directive 2000/60/CE. Official Journal of the European Communities, L327-73, 22.12.2000 
[4] Proposal for a directive of the European Parliament and of the Council on environmental quality standards in the field of water policy and amending Directive 2000/60/EC, COM (2006) 397 final.

[5] Circulaire DCE 2005/12 relative à la definition du "bon état" et à la constitution des référentiels pour les eaux douces de surface (cours d'eau, plans d'eau), en application de la directive européenne 2000/60/DCE du 23 octobre 2000, ainsi qu'à la démarche à adopter pendant la phase transitoire (2005-2007), 28 juillet 2005.www.environnement.gouv.fr.

[6] National Toxicology Program, Carcinogenesis bioassay of allyl

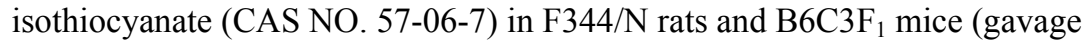
study), Technical Report Series N${ }^{\circ}$.234, October 1982. 